\title{
Selected Reference Books of 1963-1964
}

\section{INTRODUCTION}

$\mathrm{T}$ HIS ARTICLE continues the semi-annual series $^{1}$ originally edited by Constance $\mathrm{M}$. Winchell. Though it appears under a byline the list is actually a project of the reference department of the Columbia University libraries, and notes are signed with the initials of individual staff members. $^{2}$

Since the purpose of the list is to present a selection of recent scholarly and foreign works of interest to reference workers in university libraries, it does not pretend to be either well balanced or comprehensive. Code numbers (such as A11, 1A26, 2S22) have been used to refer to titles in the Guide ${ }^{3}$ and its supplements.

\section{BIBLIOGRAPHY}

Publishers' Weekly. Interim Index of Forthcoming Books. Compiled and edited by Doris Funnye, assisted by Rose Arny. v.1, no.1- . Mar. 1964- . New York: Bowker, 1964- . \$12 per year.

"To provide librarians, booksellers, and other book purchasers, at regular intervals throughout the year with the most current information on forthcoming books," Bowker now publishes this index which expands and updates the latest quarterly $P W$ anouncement number. Titles of books published since the previous announcement number appeared ase deleted (except where major changes have occurred) and fuller information for books to be released in the coming

\footnotetext{
${ }^{1}$ CRL, January and July issues starting January, 1952.

${ }^{2}$ Adele Combs, Rita Keckeissen, Sarah Ropes, Elizabeth J. Rumies, Charlotte Smith, Susan Thompson, John Neal Waddell.

${ }^{3}$ Constance M. Winchell, Guide to Reference Books (7th ed.: Chicago: ALA, 1951) : Supplement (Chicago: ALA, 1954) ; Second Supplement (Chicago: ALA, 1956); Third Supplement (Chicago: ALA, $1960)$; Fourth Supplement (Chicago: ALA, 1963).
}

months is listed. There are two separate listings, one by author, the other by title. Each gives author, title, publisher, publication date and price. To date, "at regular intervals" appears to mean quarterly.-R.K.

\section{Library Catalog}

London. University. School of Oriental and African Studies. Library. Library Catalogue. Boston: G. K. Hall, 1963. 28v. $\$ 1600$.

Contents: v.1-8, Authors; v.9-13, Titles; v.14-21, Subjects; v.22, Manuscripts and Microfilms; v.23-24, Chinese Titles; v.2526, Chinese Authors; v.27, Chinese Subjects; v.28, Japanese.

As an index to one of the great collections of materials for Oriental and African studies. this catalog should be among the most useful of the many recent reproductions of card catalogs in book form. The library contains over a quarter-million items in the fields of language and literature, history, religion, law, art, anthropology and ethnology, "and a start has been made on building up collections in the social sciences." (Pref.)

The main catalog is in three sections (v.1-21 as published): authors, titles, and subjects. The author section includes all main entries (except those in Chinese and Japanese), with some analytics for series, periodical articles, and parts of books. The title section merely provides references to the author part. In the subject section cards are grouped chiefly by region, country or language, appropriately subdivided; these categories in turn are grouped by larger region as follows: v.14, General; v.15, Africa; v.16-17, Middle East; v.18-19, South Asia; v.20, Southeast Asia and Pacific Islands; v.21, Far East. Since there are few cross references, a list of subject headings or an index to the larger subject categories would have been helpful. In the language sections, for example, material is grouped by language family, subdivided by 
individual language, but with no cross reference from the individual name to the parent group. Libraries not interested in the complete catalog may purchase separately the volume or volumes covering specific subject sections.-E.S.

\section{International Meetings}

Bibliography of Proceedings of International Meetings. Bibliographie des comptes rendus des réunions internationales. 1957- . Brussels: Union of International Associations, 1963- . 388p. $\$ 8$ (paper), $\$ 10$ (cloth).

First of a series, this volume lists published official reports and working papers, or refers to summary reports in periodicals, of conferences, congresses, symposia, round tables, etc., of international governmental and nongovernmental organizations (including the UN) and international meetings organized by national groups. Organizations are arranged by date of meeting in the body of the work, followed by an author-subject index. Among the information given is formal title (usually in the language of the published volume), paging, form of publication, UDC number and, sometimes, brief notes on contents and number of participants. The bibliography supplements the monthly Bibliographical Current List of Papers, Reports and Proceedings of International Meetings (1961- ); were it to be issued more promptly, it would be an even more useful aid.-E.J.R.

\section{Periodicals}

America: History and Life; $a$ Guide to Periodical Literature. Editor: Eric Boehm. v.1, no.1- , July 1964- . Santa Barbara, Calif:: published by Clio Press for the American Bibliographical Center, 1964- . 3 nos. a year. Service basis.

To appear thrice yearly, this is the first issue of "a bibliographic review of (1) articles on the history of the United States and Canada published throughout the world, and (2) articles dealing with current American life and times [on] all phases of American studies." (Introd.) This issue classifies 1059 articles on North America in general and the United States appearing in periodicals and serials of 1963, primarily in the humanities and social sciences. Each article is cited fully, with inclusive pagination and an abstract. Articles on Canada will appear in the second issue (December); a list of periodicals surveyed and an annual index in the third (March). Subscribers to America may utilize its periodicals information service, and obtain from it, at cost, reprints or photocopies. The quality of its advisory and editorial boards, its format and scope, are such as to make America a promising addition to reference collections. -E.J.R.

Goldwater, Walter. Radical Periodicals in America, 1890-1950. New Haven: Yale University Library, 1964. 51p. $\$ 5$.

This annotated bibliography of radical periodicals (defined by the compiler as those periodicals of an anarchist, communist, or socialist nature) includes periodicals in the English language published in the United States. With some exceptions, daily newspapers, purely trade union publications, local publications, literary magazines, and periodicals appealing to special groups are excluded. In addition to the bibliography, the book contains a list and "genealogy" of radical parties and groups.-A.C.

\section{ReLigion}

Dheilly, Joseph. Dictionnaire biblique. Tournai: Desclée, 1964. 1260p. 34 fr.

Reicke, Bo and Rost, Leonhard. BiblischHistorisches Handwörterbuch; Landeskunde, Geschichte, Religion, Kultur, Literatur. Bd.1- . Göttingen: Vandenhoeck \& Ruprecht, $\left.{ }_{[} \mathrm{c}^{1962}\right]^{-}$. (In progress.) DM. 48 , - per vol. (?)

Despite the recent appearance of several English language Bible dictionaries, these two foreign titles merit mention here. The Reicke and Rost work is the more ambitious of the two and, as the title suggests, emphasis is on understanding Biblical and related terms, including personal and place names, in their historical context and in the light of recent scholarship and archaeological research. It is designed to fill the gap between highly specialized works for theologians and the very general works. Articles are signed, many are of considerable length, 
and nearly all carry bibliographical references. Numerous maps, plates, and line drawings illuminate the text. Volumes 1-2 cover through the letter "O"; a third will follow.

The Dheilly volume is a relatively modest work with entries ranging from single-line statements to articles of several pages, and dealing with people and institutions, the books of the Bible, biblical themes, and the history and geography of biblical places. Findings of archaeological research, development of theological concepts, use of specific texts in the Catholic liturgy, and applications to art and literature are noted when pertinent.-E.S.

\section{Social Sciences}

Communist China Yearbook, 1962- . Hong Kong: China Research Associates, 1963- . (Annual?) (Distributed by Stechert-Hafner, New York.) \$10.75.

Although the foreword states that the work "contains no information of pure propaganda nature," this first yearbook is primarily a compilation of reprints from Chinese newspapers and journals-editorials, speeches, official statements, etc.-on a variety of current affairs as they existed in 1961 and early 1962. The first section, "Major meetings and statements," is followed by such categories as political, military, people's communes, economic, cultural and diplomatic relations, the last subdivided by country. Included as a part of the section on political affairs is an eighty-page directory of national and party officials. There is no index.-J.N.W.

Gould, Julius and Kolb, William L., eds. A Dictionary of the Social Sciences. New York: Free Press of Glencoe, 1964. 761p. $\$ 19.50$.

This first volume in Unesco's projected series of unilingual dictionaries in the social sciences was prepared by a joint committee of British and United States scholars. Its aim is "to define the key concepts most widely employed in the various social science disciplines . . . in a fuller and more comprehensive treatment than has proved possible in other works styled as dictionaries." (Foreword.) It defines and de- scribes in the form of incisive essays some two thousand terms and concepts in the fields of anthropology, economics, political science, social psychology and sociology. No one field predominates although social psychology would appear to be given stronger emphasis than in most previous works of this nature.

While the essays, written and signed by internationally recognized experts, are more extensive than the mere defining of terms, the material is selective. Unduly technical terms or ones with only minor or local interest are omitted. Also excluded are terms about which there is little dispute or which would appear in a standard dictionary. Common usages are given as well as the most accepted scientific usages. Illustrations are made by quotations from the standard literature in the fields, thus providing useful bibliographic references.-C.S.

White, Carl M. and Associates. Sources of Information in the Social Sciences; A Guide to the Literature. Totowa, N.J.: Bedminster Press, 1964. 489p. $\$ 10.50$.

Designed primarily for graduate library school students, this work should be useful as well to many librarians and research workers in a wide range of the social sciences. Eight principal chapters treat, respectively, social science in general, history, economics and business, sociology, anthropology, psychology, education, and political science. Each consists of two main sections: first, a bibliographic essay written by a specialist to explain the history and the methodology of the discipline, and to cite, as applicable, a substantial number of pertinent, significant monographs. The second part is devoted to annotated lists of reference sources, grouped by form, type, or specialized aspect, e.g., guides to the literature, abstracts, current bibliographies, retrospective bibliographies, encyclopedias, handbooks, etc. Periodical sources are generously cited as well as monographs and multivolume sets. The index includes authors and titles, but not subjects.-J.N.W.

\section{Dictionaries}

Erdsiek, Gerhard and Dietl, Clara-Erika. Wörterbuch für Recht, Wirtschaft und Politik, mit erläuternden und rechtsver- 
gleichenden Kommentaren. Pt.1- . Schloss Bleckede bei Hamburg: Meissners Verlag, 1964-

Contents: Pt.1, English-German, A-K, 300 p.

Added title page in English; Introduction in German and English.

Recognizing the differences between continental and Anglo-American legal systems and their respective historical backgrounds and development, the editors offer this aid to interpreters and translators. Legal, economic, and political terms are included, with "particular attention . . . to commerce and industry, banking, insurance and shipping, stock exchange practice, taxation, advertising, and public opinion research." (Introd.) For most entries the English term is followed by the equivalent German term or terms, with illustrations of idiomatic use when appropriate. Explanatory notes are provided in cases where the British or American term differs in meaning from the closest German equivalent; differences in British and American usage are also indicated.-E.S.

Harrap's Standard German and English Dictionary. Edited by Trevor Jones. London: Harrap, 1963- .v.1- .

Contents: Part 1, German-English, A-E. 541p. 80 s.

This is the first volume of a wholly new dictionary, intended as "a German counterpart to [Harrap's standard French and English Dictionary." (Pref.) Preliminary matter includes a preface (in English and German) setting forth standards, inclusions, omissions, arrangement; a pronunciation chart (International Phonetic Association principles); a table of strong and irregular verbs; and a list of labels and abbreviations used. The roman type and three-column format is extremely clear. Use of boldface, italics, and various punctuation marks unmistakably sets off the various meanings of a term; familiar or vulgar usage is so labeled. The emphasis is on providing clear English equivalents (with North American variants noted when necessary) for the "indispensable" modern German vocabulary. Its extensiveness, excellent layout and clear definitions characterize this as an- other fine addition to the corpus of modern language dictionaries.-E.J.R.

\section{SCIENCE}

Battelle Memorial Institute, Columbus, Ohio. Directory of Selected Scientific Institutions in the U.S.S.R. With an introduction to the administration of science and technology in the USSR. Prepared for the National Science Foundation. [Columbus: C. E. Merrill Books, 1963,. 1134p., indexes. \$14.75.

With a view to providing "American scientists with (1) background knowledge of the administration of science and technology in the USSR and (2) an acquaintance with selected Soviet institutions and . . . important members of their staffs" (Introd.), the directory lists for each institution the name (translated and in transliteration), address, director, administrative affiliation, selected staff members, and brief description of the institution. The list is heavily oriented toward the physical sciences, omission being made of biological and medical institutions. Information is relatively current, only literature published since 1957 being used as sources. There are indexes of transliterated titles of institutes, subjects, and staff members, and a keyword index of titles.-C.S.

Martin, Ralph C. and Jett, Wayne. Guide to Scientific and Technical Periodicals; $a$ Selected and Annotated List of Those Publishing in English. [Denver ${ }_{]}$: Swallow, [c1963]. 170p. $\$ 3.75$.

This list, which "identifies and describes briefly the editorial requirements" of 320 of the major technical periodicals which accept and publish English language articles, is addressed to "scientific and technical personnel, students, writers, and librarians." (Introd.) Titles are arranged alphabetically within large classes, subdivided where necessary. In addition to long sections for pure and applied sciences, there is a short list of social science journals included. The work is comparable to the Byrd and Goldsmith Publication Guide (Guide 4R3) and the Gerstenberger and Hendrick Directory of Periodicals (Guide 4R4) for literary and linguistic scholars.-R.K. 
Marton, Tibor W. Foreign-Language and English Dictionaries in the Physical Sciences and Engineering; A Selected Bibliography, 1952-1963. Washington: 1964. 189p. \$1.25. (U.S. National Bureau of Standards. Miscellaneous Publication 258.)

In view of the relatively limited period of coverage, it is somewhat staggering to find more than twenty-eight hundred items in this bibliography of "unilingual defining glossaries, dictionaries, encyclopedias and bi- or multilingual dictionaries in the physical sciences and technology." (Introd.) Since usefulness of the work cited to the English speaking scientific community was the principal selection criterion, a majority of the works have English as one of the languages employed, though nearly fifty foreign languages are represented. The bibliography is arranged by language within 49 subject classes; author, language and detailed subject indexes are provided.-E.S.

\section{ANTHROPOLOGY}

Greenway, John. Bibliography of the Australian Aborigines and the Native Peoples of Torres Strait to 1959. Sydney: Angus and Robertson, [1963]. 420p. $255 s$.

So comprehensive a work as this one should be especially welcome since there is no other recent bibliography of the Australian aborigines. Working in Australian, European, and American libraries, the compiler has assembled 10,283 entries, almost exclusively books and periodical articles. A few government documents, newspaper articles and book reviews have been included, but these chiefly for writings of outstanding anthropologists. There is a separate alphabetical listing of the aboriginal tribes as well as a map giving their locations, and the somewhat unconventional index provides a good subject approach. The work does for Australian ethnology what Murdock's Ethnographic Bibliography of North America (Guide N312) does for the American Indian.-C.S.

\section{Music}

Shapiro, Nat. Popular Music; an Annotated Index of American Popular Songs. ${ }_{[} \mathrm{New}$
York : Adrian Press, [1964- ]. v.1- . Contents: v.1, 1950-1959. 345p. \$16.

Seven volumes are planned in this series which aims to provide an annotated list of the "significant" popular songs of the twentieth century. Included are "those musical works which (1) achieved a substantial degree of popular acceptance, (2) were exposed to the public in especially notable circumstances, or (3) were accepted and given important performances by influential dramatic artists." (Pref.) This first volume lists songs of the fifties, arranged by year, then alphabetically by song title. Information given includes lyricist, composer, publisher, notes about best selling records, title of film or stage show in which a song was introduced, and performers associated with it. An index of titles provides references to the appropriate year; cross references are made from some, but not all, variant titles. Other volumes will deal with earlier decades of this century.-E.S.

\section{Literature}

Guide littéraire de la France, établi par Raymonde Bonnefous [et al.] ${ }_{[}$Paris $_{]}$: Hachette, ${ }_{[} \mathrm{c} 1964$ ]. 836p. Maps. 28.69 fr.

Like the well-known Guide bleu for France, this work is arranged in geographical sections, beginning with Paris, which in turn are broken down into itineraries. This correspondence permits complementary use of the two guides, although the present book's chief value may well be for armchair travelers and for reference work. There are, for example, interesting literary maps such as those showing Parisian salons in the eighteenth century or LaFontaine's trip to Limousin in 1663. All kinds of literary associations are given, whether with an author's life or with his work. The scope is not limited to French literature and the concept of "author" is broadly interpreted, although no living persons are included. Not only writers of belles-lettres and philosophy are represented, but also artists, politicians, and scientists whose work was important to literature. The section on Paris is necessarily sketchy since the literary associations here alone would fill many books. There are three indexes: the streets of 
Paris, other place names, and authors' names. The book received official sponsorship from several sources, including the Service des Lettres of the Ministère des Affaires Culturelles. This is a useful and pleasant guide which may well serve as a model for other countries.-S.T.

Stevenson, Lionel, ed. Victorian Fiction; a Guide to Research. Cambridge: Harvard University Press, 1964. 440p. \$7.75.

Students and scholars specializing in Victorian literature are particularly fortunate in having such good bibliographic coverage for their period. This newest aid is a companion to Faverty's Victorian Poets (Supplement 3R52). Following the plan of that volume (a general section followed by individual chapters on the principal novelists, each done by an outstanding scholar) and, like it, sponsored by the Victorian Literature Group of the Modern Language Association, the work provides a readable survey of research and a critical evaluation of writings in the field. Gaps in scholarship and areas for further research are frequently pointed out. Emphasis is on publications of the last quarter-century, with coverage through 1962 plus some 1963 items.-E.S.

\section{BIOGRAPHY}

Namier, Sir Lewis Bernstein, and Brooke, John. The House of Commons, 17541790. New York: published for the History of Parliament Trust by Oxford University Press, 1964. 3v. $\$ 70.60$.

Contents: v.1, Introductory survey, constituencies, appendices; v.2, Members, A-J; v.3, Members, K-Y.

The long planned, long awaited History of Parliament formally commences with these monumental volumes, products of great scholarship and industry. The "basic elements," the biographical sketches in v.2-3 (1300p.), list every member returned at the general election of 1754 and subsequent elections to 1790; they range from a few lines to eight or ten pages. It must be remembered that the plan of the History is such that each biography treats only of the part of the member's career which falls between 1754-1790, and extra-House ac- tivities are only touched on. Earlier or later sections of the History will deal with other periods when a member's term was of longer duration. The "Introductory Survey" in v.1 is a mine of information on political, social, and constitutional developments, discussing the character and development of the House and individual constituencies, groupings of members, elections, growth of party, and so on. Constituencies are then alphabetically listed and discussed, with each member and date of service noted. Manuscript sources are often indicated. Appendices give some tabular information. This is a very specialized but very valuable work.-E.J.R.

Turkevich, John. Soviet Men of Science. Princeton: Van Nostrand, 1963. 44lp. $\$ 12$.

Biographies of leading Soviet scientists are here arranged alphabetically and range in length from a few lines to several pages. In addition to date of birth, institution of higher education, date of graduation, dates and places of employment, most biographies give some details concerning the field of research, any inventions, theories or designs, bibliographical references, biographical references, office and residential addresses, and even telephone numbers. Information for the biographies was obtained from sources in Soviet literature and individual scientists were given an opportunity (which many took) to correct their biographies.-A.C.

\section{Atlas}

Atlas of Southeast Asia; with an introduction by D. G. E. Hall. London: Macmillan; New York: St. Martin's Press, 1964. 84 p. $35^{\mathrm{cm}} . \$ 8.50$.

Second in a projected series of regional atlases (the first was Atlas of the Arab World and Middle East; Supplement $4 \mathrm{~V} 164$ ), this work offers attractive colored maps showing various aspects of the following characteristics: political divisions, climate, vegetation, population, mineral resources, and communications. There are also "town plan" maps for major cities, and historical maps of the entire area for different periods appear on the endpapers. 
Southeast Asia as a whole is covered first, followed by more detailed maps for each country in the area: Philippines, Indonesia, Singapore, Malaya, Thailand, Burma, with North and South Vietnam, Cambodia, and Laos grouped under "Indochina." The main section of maps is followed by a brief illustrated history and description of the area. An index to political and geographic place names is provided.-A.C.

\section{HistoRy}

Beers, Henry Putney. The French and British in the Old Northwest; A Bibliographical Guide to Archive and Manuscript Sources. Detroit: Wayne State University Press, 1964. 297p. \$9.

Combining history and bibliography, Beers "presents an historical account of the acquisition, preservation, and publication ... of the original records created by French and British officials in the Old Northwest" (the area south of the Great Lakes from western New York to the Dakotas). The general history and governmental organization of the area under the two regimes in the eighteenth century is outlined first, followed by a description of the administrative, legal, notarial, land, and ecclesiastical records, and how and where they have been preserved in manuscript collections and public archives. The concluding section is an extensive list of primary and secondary bibliographical sources. -S.R.

Brasseur, Paule. Bibliographie générale du Mali (Anciens Soudan Français et HautSénégal-Niger). Dakar: IFAN, 1964. 461p. (Institut français d'Afrique Noire. Catalogues et documents, XVI.)

Some forty-nine hundred items on the general and physical characteristics, history, archaeology, social and economic aspects of the area which is now the state of Mali are here listed in subject arrangement. Both books and periodical articles are included, but a certain selectivity was exercised. Many entries are annotated, and there is an author-subject index. Joucla's Bibliographie de lAfrique Occidentale Française (Guide V132) provided the basis for listings to 1937, care being taken to correct errors and omissions from that volume. The year 1960, the date of total independence for Mali, was chosen as the cutoff date.-E.S.

\section{Devoto, Andrea. Bibliografia dell'oppressi- one nazista fino al 1962. Firenze: Olschki, 1964. 149p.}

Disclaiming completeness, the editor offers this listing of some fifteen hundred items as the first substantial bibliography on the Nazi concentration camp. Books and periodical articles in many languages are arranged in four main sections with appropriate subdivisions: (1) general aspects of the camps (with subdivisions for atrocities, Jewish persecution, medical aspects, etc.), (2) the principal concentration camps, (3) "secondary" or less well known camps, and (4) writings on camps not identified by name, and on the camps of the early years 1933-34. There is an author index.-E.S.

\section{Diccionario Porrúa de historia, biografía y geografía de México. México: Editorial Porrúa, [1964]. 1721p. p. 200.}

Following the general format of the 1910 Diccionario de geografía, historia y biografías Mexicanas, Porrua now presents a modern encyclopedia of Mexico. The biographies are generally limited to men no longer living or who are retired from active public life, and include a list of authors' works. The articles are quite brief (100-150 words) except in the case of major historical figures, events, and geographical areas. An especially valuable feature is the inclusion of entries for Mexican periodicals and organizations, giving names connected with each and a brief historical sketch. Ten colored maps illustrate various resources and communications systems. - S.R.

Dictionnaire de Paris. Paris: Libraire Larousse, [1964]. illus. 591p. $80.80 \mathrm{fr}$.

There are almost too many books about Paris; fortunately, this one is of more than usual interest. Although it contains no bibliographies, it does present a large amount of material in an easily usable form. The book consists of detailed articles on the physical and social institutions of Paris, 
from the beginning to present times, arranged alphabetically. Articles are entertainingly written by identified specialists, including several museum curators. The historical viewpoint is stressed, but not at the expense of amusing or picturesque detail. The wealth of excellent illustrations-photographs, engravings, colored plates of paintings, etc.-is an important feature. Although names of people are not indexed, there is an index to Paris place names which covers whole articles, references in other articles, and illustrations. For libraries or individuals interested in the history of Paris, the dictionary should prove a valuable compendium of out-of-the-way information.-S.T.

Eager, Alan R. A Guide to Irish Bibliographical Material; Being a Bibliography of Irish Bibliographies and Some Sources of Information. London: The Library Association, 1964.392 p. $96 s ; 72 s$ to members.

To help compensate for the lack of a national bibliography of Ireland, this "exploratory" volume, "basically a bibliographical index covering the hitherto unexplored field of Irish enumerative bibliography . . . aims to serve as a quick reference guide... [for Irish studies and research work." (Introd.) Included are catalogs, bibliographies -both separately published and those appended to books and articles-periodicals, indexes, unpublished work, and other primary sources. Even individual journal articles of a bibliographical character fall under the author's "sources of information." Material is arranged roughly by Dewey classification with appropriate subdivision. Entries with full information are numbered serially and listed alphabetically by author. Subject and author indexes make for ease of reference.-R.K.

Halasz de Beky, I. L. A Bibliography of the Hungarian Revolution, 1956. Toronto $_{1}$ : University of Toronto Press, [1963]. 179 p. $\$ 5$.

More than twenty-one hundred items on the 1956 Hungarian Revolution and its consequences are listed in this bibliography which covers the period from October 1956 to December 1960. Arrangement is by the thirteen languages included, and within each language section items are grouped as books and pamphlets or as periodical articles. Titles are given in the original language, with some exceptions: Hungarian and Slavic book titles are followed by English translations, but article titles in those languages are given only in English. Appendixes include lists of motion pictures, monitored broadcasts, periodicals cited, and bibliographical sources. There is an authortitle index.-A.C.

Jilek, Heinrich, Rister, Herbert, and Weiss, Hellmuth, eds. Bücherkunde Ostdeutschlands und des Deutschtums in Ostmitteleuropa. Köln: Graz, Böhlau, 1963. 560p.

(Ostmitteleuropa in Vergangenheit und Gegenwart.) DM. 68.

By stringent selection of some seventysix hundred references the editors have attempted to organize basic materials for research on East Germany and German nationals in East Central Europe (including the Baltic countries), and thus lessen problems arising from either a profusion of unselective bibliographies or none at all, and from the present-day political division of Germany and its consequences. A general section on East Central Europe precedes individual groupings for East and West Prussia, Pomerania, the Sudetenland, Posen, etc. Within each section are grouped bibliographical aids, journals and series, and references to books, articles, and dissertations on the political, social, economic, cultural, and religious history of these areas. The preponderant language of materials cited is German; science is excluded. Format is clear, and indexes of three hundred columns will prove most useful for quick reference and verifications.-E.J.R.

Johnson, Albert Frederick. A Bibliography of Ghana, 1930-1961. ${ }_{[}$Accra ${ }_{\text {] }}$ : published for the Ghana Library Board by Longmans, 1964. 210p. $42 s$.

Although somewhat different in scope, this work is largely a continuation of A. W. Cardinall's A Bibliography of the Gold Coast (published 1932; Guide V267). Coverage here includes scientific, technical, and 
purely literary works, as well as items relating to the historical, political, geographical, etc., aspects of Ghana and the Gold Coast as treated in Cardinall. Again a subject listing with author index, the new volume offers a somewhat more detailed subject breakdown than the older work. The aim was to include all book publications (except vernacular texts), with a selective listing of periodical articles. Libraries serving newly initiated African studies programs may find the sections on bibliographies, periodicals, newspapers, and directories useful as checklists.-E.S.

Velázquez, María del Carmen. Guía bibliográfica para la enseñanza de la historia en Hispano-América. México: 1964. 506p. (Instituto panaméricano de geografía e historia, Comisión de historia. Bibliografías. 2.)

Intended as a kind of "Harvard Guide" for students and teachers of Spanish Amer- ican history, this bibliography lists more than twenty-seven hundred items, mostly in Spanish. Books predominate, but some periodical articles are included. There is an extensive general section (with appropriate subdivisions for social and economic history, cultural history, diplomatic history, etc.) followed by chapters for individual countries with period subdivisions where applicable. The country sections (Brazil is omitted) usually include subsections on the general history of the country, historiography, bibliography, collections of documents, and a list of historical reviews and periodicals. Many entries are annotated or provide contents notes; unfortunately, references to the latter have not been included in the index. United States scholars and students should find the Guia an extremely useful complement to R. A. Humphreys' Latin American History (Supplement 3V133) and the Handbook of Latin American Studies.-E.S.

\section{MUSIC MANUSCRIPT}

(Continued from page 48)

of earlier styles; ${ }^{62}$ and several items by Johannes Tinctoris (ca. 1435-1511): "Terminorum Diffinitorium Musices," "Liber de Arte Contrapuncti," "Proportionale Musices." The first named is the earliest dictionary of musical terms to be printed, though not the first written (MS dates from 1476 or earlier; printed ca. 1494). ${ }^{63}$ The other two treatises are less known than the dictionary, but more important; their titles give indication of their contents. ${ }^{64}$

\footnotetext{
62 Part of the text is printed in Coussemaker, Seriptorum, II, 193-433, and a synopsis of the omitted portions is included; note that it is given under the name of De Muris, to whom it was once generally attributed despite its conflict with other Muris writings.

63 Text in Coussemaker, Scriptorum, IV, 177-91 : English translation by Carl Parrish: Dictionary of Musical Terms (Glencoe, III. Free Press, 1963).

4 Both are in Coussemaker, Scriptorum, IV, 76-177, and both have been translated into English by Albert Seay: "The Proportionale Musices of Johannes Tinctoris," Journal of Musie Theory, I-1 (March, 1957). 22-75, and The Art of Counterpoint (Rome: American Institute of Musicology, 1961). These and the other nine treatises of Tinctoris which summarize
}

\section{Conclusion}

Strictly speaking, printing did not put an end to the music manuscript period. Because of the relatively small output of new compositions by music publishers, a handwritten score must often form the only link between a composer and his audience. The scribe of the middle ages is personified today in the music copyist, who by arduous manual duplication of the composer's original makes possible performance and promulgation of the work. But now there is at least the hope of ultimate publication, and it is probably true that the best work of the best composers does get into print eventually.

So, for practical purposes, we may say that the sixteenth century saw the close of the manuscript period. The study of later music revolves around the printed score.

the body of theory up to his time, are discussed in Reese, Renaissance, 139-49. 